\title{
THE CLINICAL TRIALS LANDSCAPE IN TURKEY: AN EVALUATION OF THE ClinicalTrials.gov DATABASE
}

\author{
TÜRKIYE'DEKI KLINIK ARAŞTIRMA MANZARASI: BIR ClinicalTrials.gov VERITABANI \\ DEĞERLENDIRMESI
}

\begin{abstract}
Selçuk ŞEN ${ }^{1}$ iD
${ }^{1}$ Istanbul University, Istanbul Faculty of Medicine, Department of Medical Pharmacology, Division of Clinical Pharmacology, Istanbul, Turkey
\end{abstract}

ORCID IDs of the authors: S.Ş. 0000-0001-7878-793X

Cite this article as: Sen S. The clinical trials landscape in Turkey: an evaluation of the ClinicalTrials.gov database. J Ist Faculty Med 2020;83(3):280-5. doi: 10.26650/IUITFD.2019.0053

\section{ABSTRACT}

Objective: Clinical trials are essential tools for improving scientific knowledge and public health. With this work, it is aimed to evaluate the clinical trials landscape in Turkey.

Method: To evaluate the landscape of clinical trials in Turkey, all clinical trials registered on or before the date of 20.06.2019 in the ClinicalTrials.gov database were used. The registered clinical trials were filtered by study type, study phase, funder type, current status of clinical trials, and location. In addition, the number of clinical trials in Turkey was compared with some countries which were selected based on population and number of trials.

Results: In Turkey, the total number of registered clinical trials was 3880 . The majority of these trials (\%79.4) were interventional studies. The majority of phase trials were phase III studies, of which the vast majority were sponsored by industry. The numbers of completed and currently participants recruiting trials were 2245 and 722, respectively. Not only in Turkey, but in all countries, the numbers of clinical trials with unknown status and phase studies without defined phases were higher in trials were not funded by industry. When the numbers of first registered clinical trials were evaluated between the years of 2009 and 2018, a considerable increase was seen. The number of clinical trials in Turkey was 5 or 6 fold less than in developed countries with a comparable population such as Germany, France, and United Kingdom.

Conclusion: With this work, it was shown that the number of clinical trials in Turkey is still not as expected. In order to take its rightful place in the world, Turkey should continue to make improvements, use its potential and increase awareness in the field of clinical trials.

Keywords: Clinical Trials, Turkey, Research

\section{ÖZET}

Amaç: Klinik araştırmalar bilimsel bilginin ve toplum sağlığının iyileştirilmesi için önemli araçlardır. Bu çalışma ile Türkiye'deki klinik araştırma manzarasının değerlendirilmesi amaçlanmışıı.

Yöntem: Türkiye'deki klinik araştırma manzarasının değerlendirilmesi için 20.06.2019 tarihi ve öncesinde ClinicalTrials.gov veritabanına kayıt edilmiş tüm klinik araştırmalar kullanılmıştır. Kayıtlı klinik araştırmalar çalışma türü, çalışma fazı, destekleyici türü, çalışmanın şu anki durumu ve lokasyona göre filtrelenmiştir. Ek olarak, Türkiye'deki klinik araştırma sayısı, nüfus ve çalışma sayısına göre seçilen bazı ülkeler ile kıyaslanmıştır.

Bulgular: Türkiye' de toplam kayıtlı klinik araştırma sayısı 3880 idi. Bu araştırmaların çoğunluğu $(\% 74,6)$ müdahaleli çalışmalardı. Faz çalışmalarının çoğunluğu faz III çalışmalardı ve bu çalışmaların büyük çoğunluğu endüstri tarafından finanse edilmiştir. Tamamlanan ve şu anda aktif olarak katılımcı alan çalışma sayısı sırasıyla 2245 ve 722 idi. Sadece Türkiye' de değil, tüm ülkelerde, durumu bilinmeyen klinik araştırma ve fazı tanımlanmamış faz çalışması sayıları endüstri tarafından desteklenmeyen araştırmalarda daha fazlaydı. Türkiye'de 2009 ve 2018 yılları arasında ilk kez kayıt edilen araştırma sayıları değerlendirildiğinde, gözle görülür bir artış görüldü. Fransa, Almanya ve Birleşik Kralıı gibi nüfusu yakın gelişmiş ülkeler ile kıyaslandığında, Türkiye'deki klinik araştırma sayısı 5 veya 6 kat daha azdı.

Sonuç: Bu çalışma ile Türkiye'deki klinik araştırma sayısının hala yeterli düzeyde olmadığı gösterildi. Küresel dünyada hak ettiği yeri alması için, Türkiye klinik araştırma alanında iyileştirmeler yapmaya, potansiyelini kullanmaya ve farkındalığı arttırmaya devam etmelidir.

Anahtar Kelimeler: Klinik Araştırmalar, Türkiye, Araştırma

Corresponding author/iletişim kurulacak yazar: slcsen@istanbul.edu.tr

Submitted/Başvuru: 16.07.2019• Revision Requested/Revizyon Talebi: 22.08.2019 • Last Revision Received/Son Revizyon: 11.10.2019 • Accepted/Kabul: 24.10.2019 • Published Online/Online Yayın: 20.11.2019

(C) Telif Hakkı $2020 \mathrm{~J}$ Ist Faculty Med - Makale metnine jmed.istanbul.edu.tr web sayfasından ulaşılabilir.

CCopyright 2020 by J Ist Faculty Med - Available online at jmed.istanbul.edu.tr 


\section{INTRODUCTION}

It is a fact that clinical trials are essential tools for improving scientific knowledge and public health. Well-designed clinical trials can be beneficial to all stakeholders, including patients, investigators, industry, and health authorities. Access to new treatment options before they are available in the market, new treatment options for the patients when standard therapy has not been beneficial, more frequent visits and medical care in clinical trials, can be counted as major benefits for the patients participating in clinical trials. As a remarkable example, the National Comprehensive Cancer Network has pointed out that patients with any cancer may have the best management for their disease in clinical trials $(1,2)$. In other respects, understanding the mechanism of the disease, development of new treatments, and improvement of the existing scientific knowledge are essential for the whole community. Since all research-related expenses are under the responsibility of the sponsors, clinical trials also have an impact on the economy of the countries.

With its geographical location, a population of more than 80 million, experienced researchers and moreover, a high number of treatment naïve patients, Turkey has a great potential to increase the number and quality of clinical trials. In recent years, Turkey has taken a major step in this promising field with the support of national health authorities, by declaring and updating the national regulations, which are in compliance with the international level $(3,4)$. For conducting clinical trials in Turkey, approval of the Ethics Committee and permission of Turkish Medicine and Medical Devices Agency should be obtained. The approval and permission procedures are very similar to other developed countries. Related regulations and guidelines can be found at the website of the Turkish Medicine and Medical Devices Agency (5).

In this present work, in order to figure out the clinical trials landscape in Turkey, the number of clinical trials, study type, study phase, sponsored type and all other relevant information, were evaluated using the ClinicalTrials.gov database (6), which is one of the most known and globally used databases for the registration of clinical trials. In addition, the number of clinical trials in Turkey was compared with other countries.

\section{METHOD}

To evaluate the landscape of clinical trials in Turkey, all registered clinical trials until the date of 20.06.2019 in the clinicaltrials.gov database (6) were used. Besides, first-registered (first -posted) number of clinical trials in Turkey between the years of 2009 and 2018 were analyzed. Registered clinical trials were filtered by funder type (industry or non-industry), study type (interventional or observational), study phase and status of clinical trials (recruiting, enrolling, suspended, terminated, completed, unknown, etc.) and location.

The number of clinical trials in Turkey was compared with France, Germany, the United Kingdom, the Russian Federation, South Africa, Egypt, Argentina and Thailand. These countries were selected based on the population of the country and number of trials. In the field of clinical trials, France, Germany and the United Kingdom are the top three countries in Europe, and they have a population comparable with Turkey. The Russian Federation, South Africa, Egypt, Argentina, and Thailand are in different regions of the world, and in these countries, numbers of registered trials are comparable with Turkey. The Worldbank data (7) for the year of 2017 was used for the approximate population of the countries.

\section{Statistical analyzes}

The present work is a descriptive study. Therefore, a specific statistical test was not used. The findings were given as numbers and percentages.

\section{RESULTS}

In Turkey, the total number of registered clinical trials in the clinicaltrials.gov was 3880, and 1632 of these trials were sponsored by industry (ClinicalTrials.gov last accessed 21.06.2019). The number of interventional trials conducted with a drug or a biological agent or a device was 2494. According to the study type, the distribution was shown in figure 1 . Besides, $23.6 \%$ of the clinical trials included the pediatric population (between birth and 17 of age).

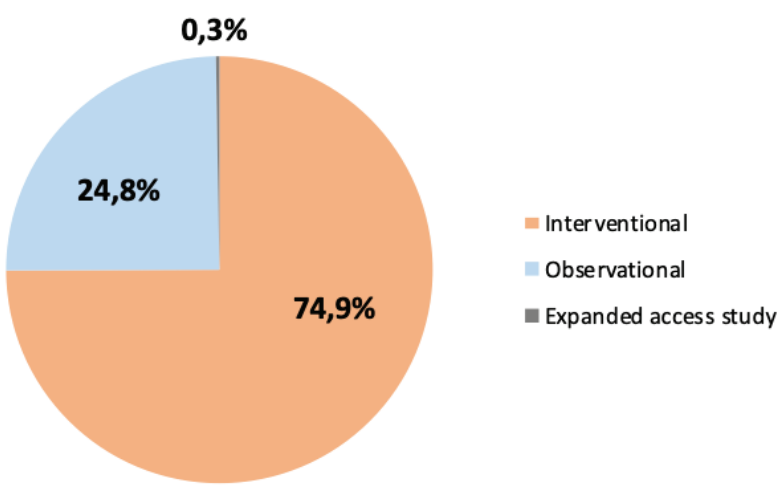

Figure 1: The study type of registered clinical trials in Turkey. The numbers of interventional, observational and expanded access studies (also called as compassionate use) were 2908 (74.9\%), 962 (24.8\%) and 10 (0.3\%) respectively.

As a study site, Istanbul and Ankara were the first and second cities where the clinical trials were mostly conducted in Turkey (Figure 2). 


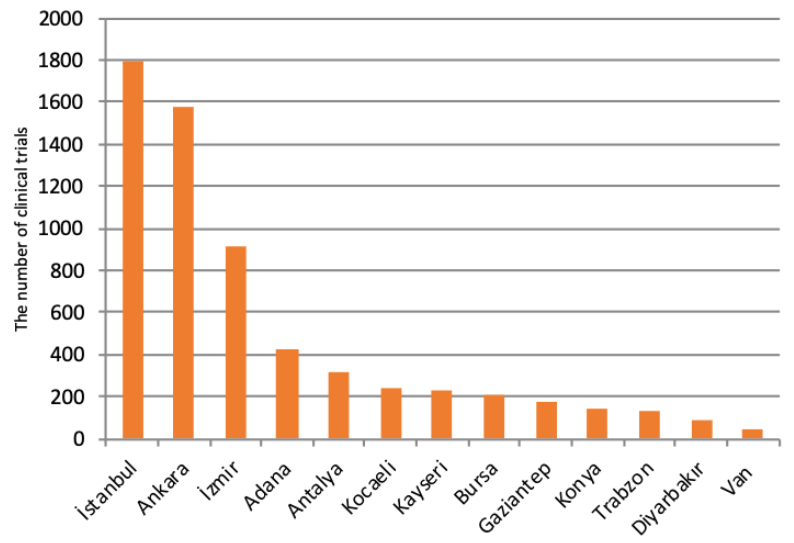

Figure 2: Locations of clinical trials in Turkey*.

${ }^{*}$ A multicenter clinical trial can be conducted in multiple locations. Therefore the total number in this figure can seem higher than 3880 which was given above.
In the present work, the distribution of clinical phase studies was also evaluated. It was shown that the majority of these trials were phase III studies, of which the vast majority was sponsored by industry. On the other hand, the majority of non-industry sponsored clinical trials were phase IV. In addition, a high number of non-industry sponsored trials without defined phases (not applicable) was determined (Figure 3).

When the first-registered clinical trials were evaluated between the years of 2009 and 2018, an increase was seen in total and non-industry sponsored clinical trials in recent years, whereas, there was a stability in first-registered trials sponsored by industry (Figure 4).

Registered clinical trials were also evaluated according to recruitment status. Numbers of completed and recruiting trials were 2245 and 722, respectively. Additionally, 322 (8.3\%) trials with unknown status were seen (Figure 5).

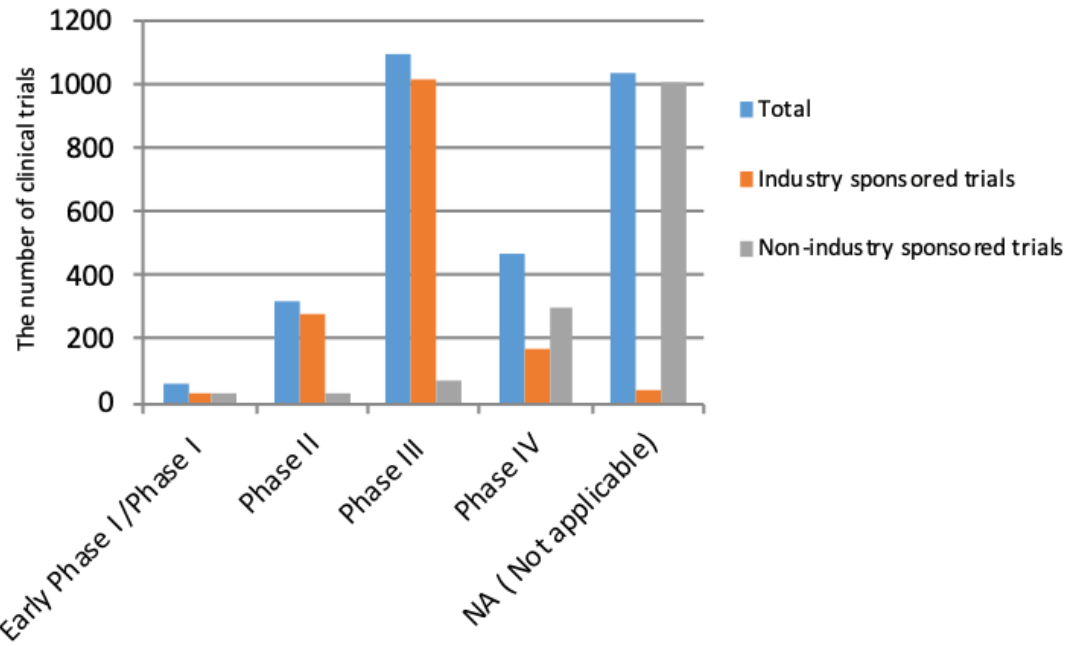

Figure 3: The distribution of clinical phase studies in Turkey.

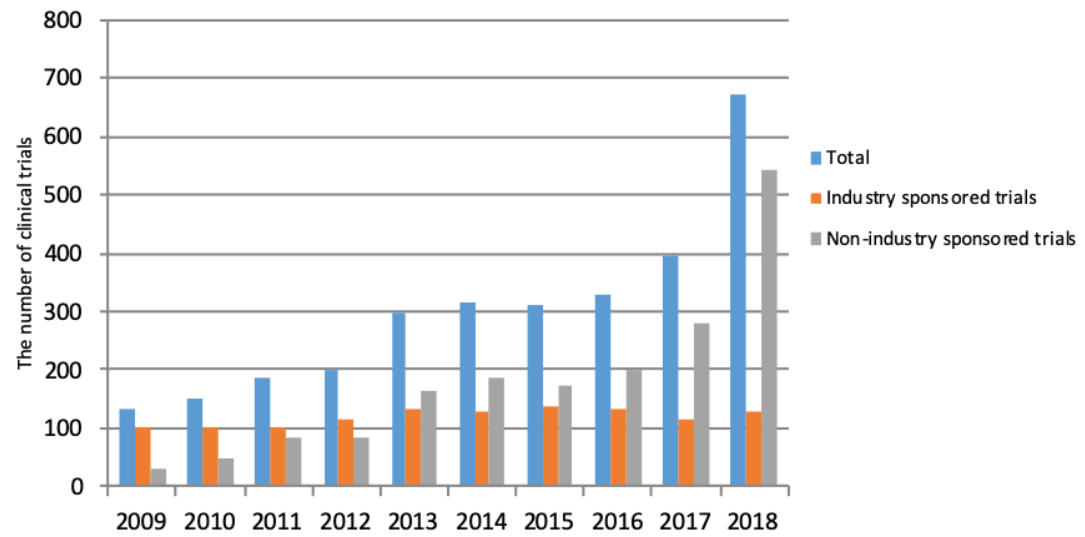

Figure 4: The number of first-registered clinical trials between the years of 2009 and 2018. 


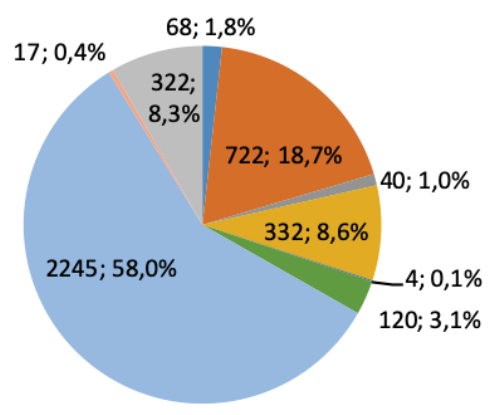

\begin{tabular}{|c|c|c|}
\hline Not yet recruiting & necruiting & Enrolling by invitation \\
\hline Active, not recruiting & -Suspended & - Terminated \\
\hline Completed & Withdrawn & Unknown status \\
\hline
\end{tabular}

Figure 5: The status of clinical trials in Turkey. Results were given as number; percentage.

Status of clinical trials are defined by ClinicalTrials.gov as; "Not yet recruiting: The study has not started recruiting participants; Recruiting: The study is currently recruiting participants ; Enrolling by invitation: The study is selecting its participants from a population, or group of people, decided on by the researchers in advance. These studies are not open to everyone who meets the eligibility criteria but only to people in that particular population, who are specifically invited to participate; Active, not recruiting: The study is ongoing, and participants are receiving an intervention or being examined, but potential participants are not currently being recruited or enrolled; Suspended: The study has stopped early but may start again; Terminated: The study has stopped early and will not start again. Participants are no longer being examined or treated; Completed: The study has ended normally, and participants are no longer being examined or treated (that is, the last participant's last visit has occurred); withdrawn: The study stopped early, before enrolling its first participant; Unknown: A study on ClinicalTrials.gov whose last known status was recruiting; not yet recruiting; or active, not recruiting but that has passed its completion date, and the status has not been last verified within the past 2 years" (6).

In regard to high number of clinical trials with unknown status, the numbers in other countries were evaluated, and a comparison was done between the industry and non-industry sponsored trials. It was demonstrated that in all countries, the numbers of clinical trials with unknown status were higher in non-industry sponsored clinical trials (Table 1).

Table 1: The number of clinical trials with unknown status.

\begin{tabular}{lccc}
\hline & Total & Industry sponsored & Non-industry sponsored \\
Turkey & 322 & 12 & 310 \\
France & 2133 & 241 & 1892 \\
Germany & 1354 & 353 & 1001 \\
United Kingdom & 1442 & 266 & 1176 \\
Russian Federation & 147 & 47 & 100 \\
Egypt & 427 & 15 & 412 \\
South Africa & 63 & 16 & 47 \\
Argentina & 67 & 21 & 46 \\
Thaliand & 260 & 19 & 241 \\
\hline
\end{tabular}

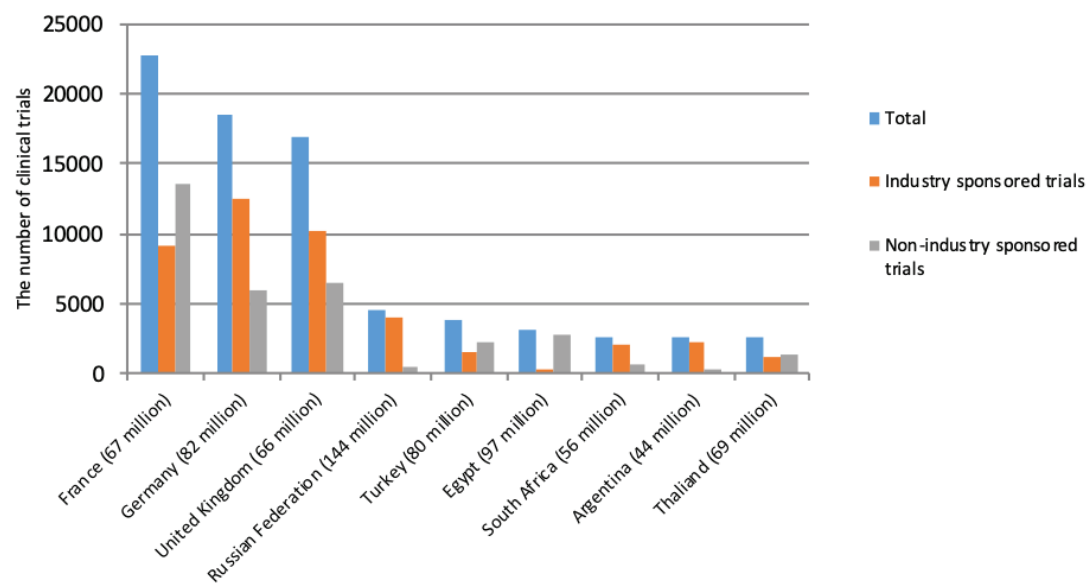

Figure 6: Comparison of clinical trials in Turkey with other countries. Countries were given as name and (approximate number of population). 


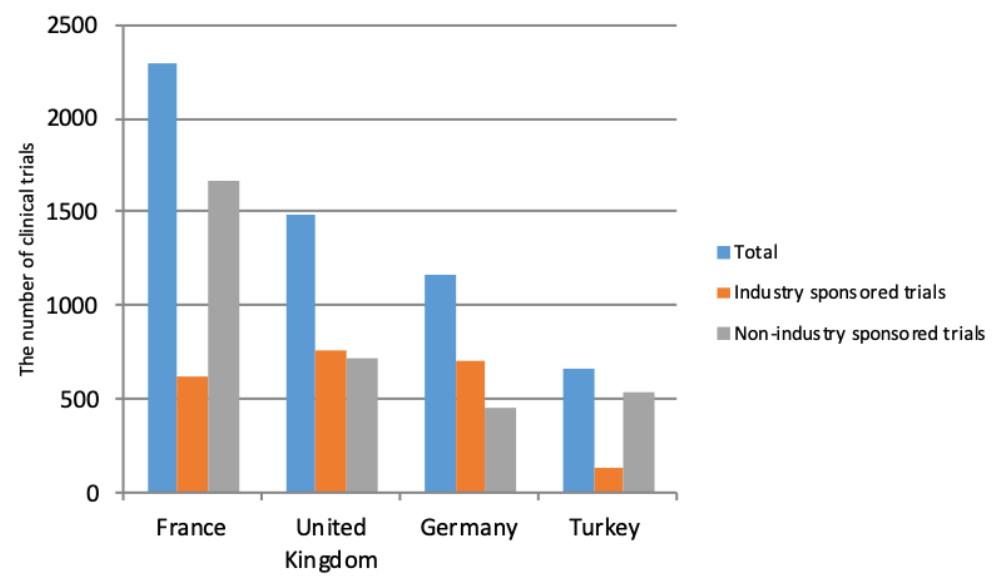

Figure 7: The number of first-registered clinical trials from 01.01.2018 to 31.12.2018 in Turkey, France, Germany and the United Kingdom.

The number of clinical trials in Turkey was less than France, Germany and United Kingdom. When the clinical trials landscape was compared with other countries which have an approximately similar number of clinical trials, the distribution of industry and non-industry sponsored clinical trials differed among the countries (Figure 6).

Number of first-registered non-industry sponsored clinical trials in Turkey was similar to the United Kingdom and a little higher than Germany, when only the year of 2018 was evaluated (Figure 7).

\section{DISCUSSION}

It is very well known that the vast majority of clinical trials are conducted in United States, Europe, and developed countries. Clinical trials are not only essential tools for improving the scientific knowledge and public health, but they are also beneficial to the countries' economy. From the beginning of the $20^{\text {th }}$ century to the present, Turkey has passed several milestones to improve the legislative regulations of clinical research. For the time being, it can be concluded that the country's legislation and regulations on clinical research are in compliance with ICH-GCP guidelines and European Directives (3). In contrast to improvement in legislative regulations, the number of clinical trials is still not as expected, especially when compared with other developed countries. In the present study, it was also shown that the number of clinical trials in Turkey was 5 or 6 fold less than in developed countries with a comparable population, such as Germany, France and United Kingdom. These countries are the top three countries in Europe in the field of clinical trials. Therefore, it is concluded that Turkey can set a goal to reach these countries' level.

In other respects, location, economic and political issues may affect the number and distribution of clinical trials. For example, in Egypt, although the total number of trials was similar to Turkey, the vast majority of the trials were non-industry sponsored. In Argentina, the Russian Federation, and South Africa the situation is just the opposite, where a vast majority were industry sponsored trials. In Thailand, it was almost equally distributed.

When the first registered clinical trials between the years of 2009 and 2018 were evaluated, the number of clinical trials in Turkey, especially the number of non-industry sponsored clinical trials, was increased considerably. As a remarkable finding, in the year 2018, the number of non-industry sponsored trials in Turkey was similar to the United Kingdom, and a little higher than Germany. In the third quarter of 2004, the International Committee of Medical Journals (ICMJE) declared that the registration of clinical trials is required as a prerequisite of publication (8). After the declaration of ICMJE, many scientific journals have started to ask for the registration of clinical trials as a requirement. The ClinicalTrials.gov database is one of the most known and easy-access databases to use for this purpose. This may explain the increase in non-industry sponsored clinical trials. Non-industry sponsored clinical trials can be defined as the trials which are funded by universities, organizations, national institutions, etc. The vast majority are academic and non-commercial studies. Probably, publication metrics may have effects on academicians' careers (9). However, this cannot be the single factor in this increase. Not only in Turkey, but also at the international level, the enhancement of the research culture and widespread use of the existing databases are the other main factors. In the last decade, although the total number of clinical trials in Turkey increased, there was stability in industry sponsored trials. It was not possible to figure out the reasons within the present work. The reasons should be deeply discussed by the relevant stakeholders.

Skepticism on scientific findings of the industry-driven clinical trials has mostly occurred due to the design and 
the target of the study, which is generally defined by the industry's objective. On the other hand, the industry is controlled by health authorities tighter than academia, and tighter monitoring elicits higher data quality. Inherent$l y$, it puts the industry one step ahead of academia in the documentation and reporting process (10). In the present study, not only in Turkey, but in all countries, the number and proportion of clinical trials with unknown status and the number of interventional trials without defined phases were much higher in the non-industry arm. These findings can confirm that academic trials have much more missing information. However, it may be concluded that learning from each other has more benefits than seeing the limitations of both approaches only. The industry can get much more support from the academicians and benefit from their expertise for the study design and the protocol. On the other hand, the industry's expertise on documentation and reporting process can be beneficial to academia (9).

In this work, the clinical trials landscape of Turkey was illuminated in some measure. The main limitation of this work was that this evaluation could not be conducted by using national databases.

\section{CONCLUSION}

With this work, it was demonstrated that the number of clinical trials is still not as expected. Although there was a considerable increase in the total number of clinical trials in recent years, the number of industry sponsored clinical trials that have an economic impact on the country, was almost stationary. However, with its geographical location and other advantages, Turkey has a great potential to increase the number of clinical trials. In order to take its rightful place in the world, Turkey should continue to make improvements, use its potential and increase awareness in the field of clinical trials. In addition, it should be kept in mind that "number" does not mean everything. Ethics and quality should also be taken into consideration.

Acknowledgement: I would like to thank to Prof. Yağız Üresin for great support

Peer Review: Externally peer-reviewed.

Author Contributions: Conception/Design of Study- S.Ş.; Data Acquisition- S.Ş.; Data Analysis/Interpretation- S.Ş.; Drafting
Manuscript- S.Ş.; Critical Revision of Manuscript- S.Ş.; Final Approval and Accountability- S.Ş.

Conflict of Interest: Author declared no conflict of interest.

Financial Disclosure: Author declared no financial support.

Teşekkür: Prof. Yağız Üresin'e büyük desteği için teşekkür ederim.

Hakem Değerlendirmesi: Dış bağımsız.

Yazar Katkıları: Çalışma Konsepti/Tasarım- S.Ş.; Veri ToplamaS.Ş.; Veri Analizi/Yorumlama- S.Ş.; Yazı Taslağı- S.Ş.; İçeriğin Eleştirel Incelemesi- S.Ş.; Son Onay ve Sorumluluk- S.Ş.

Çıkar Çatışması: Yazarlar çıkar çatışması beyan etmemiştir.

Finansal Destek: Yazar finansal destek beyan etmemiştir.

\section{REFERENCES}

1. Mhaskar R, Miladinovic B, Guterbock TM, Djulbegovic B. When are clinical trials beneficial for study patients and future patients? A factorial vignette-based survey of institutional review board members. BMJ Open 2016;6:e011150. [CrossRef]

2. Radich JP, Deininger M, Abboud CN, Altman JK, Berman E, Bhatia R, et al. Chronic myeloid leukemia, Version 1.2019, NCCN clinical practice guidelines in oncology. J Natl Compr Cancer Netw 2018;16:1108-35. [CrossRef]

3. Ilbars H, Kavakli K, Akan H, Irmak DK. Clinical Trials Journey of Turkey-Long and Thin Road. J Clin Trials 2015;5:211-5.

4. Ilbars H. Clinical Trials in Turkey. Turkish Journal of Hematology 2013;30(2):111-4. [CrossRef]

5. T.C. Ministry of Health Turkish Medicine and Medical Devices Agency. Available: www.titck.gov.tr. Accessed: 20 June 2019.

6. U.S. National Library of Medicine. Available: clinicaltrials. gov. Accessed: 21 June 2019.

7. The World Bank. Available: data.worldbank.org. Accessed: 21 June 2019.

8. Califf, RM, Zarin, DA, Kramer, JM, Sherman, RE, Aberle, LH, Tasneem, A. Characteristics of clinical trials registered in ClinicalTrials.gov, 2007-2010. JAMA 2012;307:1838-47. [CrossRef]

9. Laterre PF, François B. Strengths and limitations of industry vs. academic randomised controlled trials. Clin Microbiol Infect 2015;21:906-9. [CrossRef]

10. Heinemann L. Are all clinical studies sponsored by industry not valid? J Diabetes Sci Technol 2008;2:1161-3. [CrossRef] 